\title{
The MICA-129Met/Val dimorphism affects plasma membrane expression and shedding of the NKG2D ligand MICA
}

\author{
Antje Isernhagen $^{1}$ - Daniela Schilling ${ }^{2,3} \cdot$ Sebastian Monecke ${ }^{1,5} \cdot$ Pranali Shah $^{1}$ • \\ Leslie Elsner $^{1} \cdot$ Lutz Walter $^{4,5} \cdot$ Gabriele Multhoff $^{2,3} \cdot$ Ralf Dressel $^{1,5}$
}

Received: 19 September 2015 / Accepted: 9 November 2015 / Published online: 19 November 2015

(C) The Author(s) 2015. This article is published with open access at Springerlink.com

\begin{abstract}
The MHC class I chain-related molecule A (MICA) is a ligand for the activating natural killer (NK) cell receptor NKG2D. A polymorphism causing a valine to methionine exchange at position 129 affects binding to NKG2D, cytotoxicity, interferon- $\gamma$ release by NK cells and activation of $\mathrm{CD} 8^{+}$ T cells. It is known that tumors can escape NKG2D-mediated immune surveillance by proteolytic shedding of MICA. Therefore, we investigated whether this polymorphism affects plasma membrane expression (pmMICA) and shedding of MICA. Expression of pmMICA was higher in a panel of tumor $(n=16, P=0.0699)$ and melanoma cell lines $(n=13, P=$ $0.0429)$ carrying the $M I C A-129 \mathrm{Val} / \mathrm{Val}$ genotype. MICA$129 \mathrm{Val}$ homozygous melanoma cell lines released more soluble MICA (sMICA) by shedding $(P=0.0015)$. MICA-129Met or MICA-129Val isoforms differing only in this amino acid were expressed in the MICA-negative melanoma cell line Malme, and clones with similar pmMICA expression intensity
\end{abstract}

Antje Isernhagen, Daniela Schilling and Sebastian Monecke contributed equally to this work.

Ralf Dressel

rdresse@gwdg.de

1 Institute of Cellular and Molecular Immunology, University Medical Center Göttingen, Humboldtallee 34, 37073 Göttingen, Germany

2 Department of Radiation Oncology, Klinikum rechts der Isar, Technische Universität München (TUM), Munich, Germany

3 Institute of Innovative Radiotherapy (iRT), Radiation Immune Biology, Department of Radiation Sciences (DRS), Helmholtz Zentrum München, Munich, Germany

4 Primate Genetics Laboratory, German Primate Center, Göttingen, Germany

5 DZHK (German Center for Cardiovascular Research), Partner site Göttingen, Göttingen, Germany were selected. The MICA-129Met clones released more sMICA $(P=0.0006)$, and a higher proportion of the MICA129Met than the MICA-129Val variant was retained in intracellular compartments $(P=0.0199)$. The MICA-129Met clones also expressed more $M I C A$ messenger RNA $(P=$ 0.0047). The latter phenotype was also observed in mouse $\mathrm{L}$ cells transfected with the MICA expression constructs $(P=$ 0.0212). In conclusion, the MICA-129Met/Val dimorphism affects the expression density of MICA on the plasma membrane. More of the MICA-129Met variants were retained intracellularly. If expressed at the cell surface, the MICA129Met isoform was more susceptible to shedding. Both processes appear to limit the cell surface expression of MICA129Met variants that have a high binding avidity to NKG2D.

Keywords Single nucleotide polymorphism · Major histocompatibility complex (MHC) class I chain-related molecules A (MICA) · Plasma membrane expression . Proteolytic shedding $\cdot$ Tumor cells

\section{Introduction}

The activity of natural killer (NK) cells is controlled by activating and inhibitory natural killer receptors. NKG2D (NK group 2, member D) is an activating receptor, which is expressed mainly on $\mathrm{NK}$ cells and $\mathrm{CD} 8^{+} \alpha \beta \mathrm{T}$ cells (Champsaur and Lanier 2010; Raulet et al. 2013). NKG2D signaling triggers cytotoxicity (Billadeau et al. 2003) and cytokine secretion of NK cells (Andre et al. 2004), whereas it functions as a co-stimulatory molecule on $\mathrm{CD}^{+} \alpha \beta \mathrm{T}$ cells (Groh et al. 2001). NKG2D-mediated pathways are important for the elimination of malignant cells (Guerra et al. 2008) and for defense against some pathogens (Fang et al. 2008; Wesselkamper et al. 2008). The NKG2D receptor recognizes 
several ligands on target cells, which include the major histocompatibility complex (MHC) class I chain-related molecules A (MICA) and B (MICB) and the six members of the UL16binding proteins (ULBP1-6) (Chitadze et al. 2013; Choy and Phipps 2010).

$M I C A$ and $M I C B$ are encoded in the HLA complex (Bahram et al. 1994; Choy and Phipps 2010; Leelayuwat et al. 1994), and MICA is the most polymorphic nonclassical class I gene (http://www.ebi.ac.uk/imgt/hla/). The domain structure of MICA is similar to classical class I molecules with three extracellular domains $(\alpha 1, \alpha 2$, and $\alpha 3)$ , a transmembrane segment, and a carboxy-terminal cytoplasmic tail. However, MICA is not associated with $\beta 2$ microglobulin and does not present peptides. MICA is constitutively expressed on a few cell types, including gastrointestinal epithelium (Groh et al. 1996); however, following cellular or genotoxic stress (Gasser et al. 2005; Groh et al. 1996), it can be induced on malignant or virus-infected cells (Champsaur and Lanier 2010; Raulet et al. 2013).

Proteolytic shedding of MICA can result in a tumor immune escape mediated by immunosuppressive soluble MICA (sMICA) (Chitadze et al. 2013; Groh et al. 2002; Salih et al. 2002). Soluble MICA can induce NKG2D downregulation by rapid endocytosis and partial lysosomal degradation resulting in the impairment of NK cell cytotoxicity (Roda-Navarro and Reyburn 2009) and co-stimulation of $\mathrm{CD} 8^{+} \mathrm{T}$ cells via NKG2D. MICA is cleaved at the cell surface by members of the family of matrix metalloproteases (MMPs) and the "a disintegrin and metalloproteinase" (ADAM) family, including ADAM10 and ADAM17 (Groh et al. 2002; Kaiser et al. 2007; Salih et al. 2002; Waldhauer et al. 2008). The $\alpha 3$ domain of MICA forms a complex with the disulphide isomerase/ chaperon endoplasmic reticulum protein 5 (ERp5) on the surface of tumor cells, which induces a conformational change enabling the proteolytic cleavage of MICA. Shedding of NKG2D ligands has been reported for many cancers and some hematopoietic malignancies (Chitadze et al. 2013). Not only sMICA but also tumor-derived exosomes, which contain MICA (Clayton et al. 2008), may contribute to a downregulation of NKG2D. A number of clinical studies showed an association between tumor-associated or soluble NKG2D ligands and disease progression and poor prognosis in different malignant diseases (El-Gazzar et al. 2013). Taken together, these tumormediated counter-regulation mechanisms appear to contribute to tumor evasion from $\mathrm{NK}$ cell and $\mathrm{CD} 8^{+} \mathrm{T}$ cell-mediated immunity.

Several MICA polymorphisms have been reported to affect MICA shedding including a single nucleotide polymorphism (SNP) in the promoter region, a microsatellite in exon 5 encoding the transmembrane region, and the MICA-129Met/ Val dimorphism in $\alpha 2$ domain of the MICA protein.

The SNP at -1878 (rs2596542) in the promoter region of the MICA gene was found to be associated with the risks of hepatitis C (Kumar et al. 2011) and hepatitis B virus-induced hepatocellular carcinoma (Kumar et al. 2012; Tong et al. 2013). In all three studies, an association of higher sMICA serum levels with the $G$ allele was observed. The $G$ allele was found to have a higher transcriptional activity (Lo et al. 2013), which might explain the effects on sMICA serum levels indirectly by higher MICA expression intensities.

The transmembrane region of MICA, encoded in exon 5, contains a polymorphic microsatellite, which varies in the number (4 to 9) of alanine encoding GCT repeats (Fodil et al. 1996; Mizuki et al. 1997; Ota et al. 1997). The MICAA5.1 polymorphism contains five triplet repeats plus one additional insertion (GGCT/AGCC) causing a frame shift, which results in a premature stop codon in the transmembrane region. $M I C A$ alleles containing the MICA-A5.1 variant, such as $M I C A^{*} 008$, have a number of unique features including recruitment of the protein to exosomes, which might be explained by acquisition of a GPI (glycosylphosphatidylinositol) anchor by this modification that replaces the transmembrane domain (Ashiru et al. 2013). The MICA-A5.1 polymorphism has been associated with autoimmune diseases (Fojtikova et al. 2011; Lü et al. 2009; Novota et al. 2005; Triolo et al. 2009), the risk of cytomegalovirus reactivation in HIV-1infected patients (Moenkemeyer et al. 2009), and several malignancies (Chen et al. 2013; Jiang et al. 2011; LavadoValenzuela et al. 2009; Luo et al. 2011; Tamaki et al. 2007; Tian et al. 2006; Tong et al. 2013). Moreover, donor MICA A5.1 genotype and anti-MICA sensitization was identified as a risk factor for kidney transplant survival (Tonnerre et al. 2013). In patients with oral squamous cancer (Tamaki et al. 2009) and in patients with hepatocellular carcinoma (Jiang et al. 2011), the $A 5.1$ genotype was associated with higher sMICA serum levels, and Raji cells constructed to express the MICA A5.1 allele produced more sMICA than cells transfected to express a full-length MICA $A 5$ allele (Lü et al. 2009).

The SNP (rs1051792) at nucleotide position $454(G / A)$ of the MICA gene, which leads to an amino acid substitution from valine (Val) to methionine (Met) at position 129 in the $\alpha 2$ domain of the MICA protein, has been described to affect NKG2D binding avidity (Steinle et al. 2001). This SNP has been associated with the risk of nasopharyngeal carcinoma (Douik et al. 2009), hepatitis B virus-induced hepatocellular carcinoma (Tong et al. 2013), chronic (Boukouaci et al. 2009) and acute graft versus host disease (Isernhagen et al. 2015), the risk of ventricular systolic dysfunction in chronic Chargas heart disease (Ayo et al. 2015), and a number of autoimmune diseases, including ankylosing spondylitis (Amroun et al. 2005), rheumatoid arthritis (Kirsten et al. 2009), inflammatory bowel disease (Lopez-Hernandez et al. 2010; Zhao et al. 2011), lupus erythematosus (Yoshida et al. 2011), type I diabetes (Raache et al. 2012), and psoriatic disease (Pollock et al. 2013). In patients with ulcerative colitis, the MICA-129Val/Val 
genotype was associated with higher sMICA serum levels (Zhao et al. 2011) and the MICA-129Met allele was associated with lower sMICA serum levels in hepatitis B virus-induced hepatocellular carcinoma patients and healthy controls (Tong et al. 2013).

Tong and colleagues correlated 10 MICA polymorphisms with sMICA serum levels in hepatitis B virus-induced hepatocellular carcinoma patients (Tong et al. 2013). In addition to associations mentioned before, they found significantly higher sMICA serum levels associated with the coding variants $M I$ CA-175Ser and MICA-251Arg and the microsatellite variants $A 4$ and $A 9$ (Tong et al. 2013).

We recently described that the high-avidity MICA-129Met variant is characterized by stronger and faster NKG2D signaling, triggering of more NK cell cytotoxicity and interferon- $\gamma$ release, a rapid co-stimulation of $\mathrm{CD} 8^{+} \mathrm{T}$ cells but also a rapid downregulation of NKG2D (Isernhagen et al. 2015). Therefore, we compared herein the MICA-129Met and MICA$129 \mathrm{Val}$ variants also with respect to MICA expression and shedding.

\section{Methods}

\section{Cell culture and transfection}

The human tumor cell lines H1339, EPLC-272H, A549 (lung), FaDu, SAS, Cal33, BHY, UT15 (squamous cell carcinoma of the head and neck), CX2, HCT116 (colon), Panc-1 (pancreas), MCF-7, T47D, MDA-MB-231 (breast), and Hela (cervix) were cultured in Roswell Park Memorial Institute (RPMI) 1640 medium (Sigma-Aldrich, Taufkirchen, Germany) supplemented with $10 \%$ fetal calf serum (FCS) (Sigma-Aldrich), $2 \mathrm{mM}$ L-glutamine, $1 \mathrm{mM}$ sodium pyruvate $100 \mathrm{IU} / \mathrm{ml}$ penicillin, and $100 \mu \mathrm{g} / \mathrm{ml}$ streptomycin. Human melanoma cell lines (Dressel et al. 1998) and mouse fibroblast $\mathrm{L}$ cells were maintained in $\mathrm{NaHCO}_{3}$-buffered Dulbecco's modified Eagle medium (DMEM) supplemented with $10 \%$ FCS (Biochrom, Berlin, Germany), $2 \mathrm{mM}$ L-glutamine, $1 \mathrm{mM}$ sodium pyruvate, $50 \mu \mathrm{M} 2$-mercaptoethanol, $100 \mathrm{U} / \mathrm{ml}$ penicillin, and $100 \mu \mathrm{g} / \mathrm{ml}$ streptomycin. Cell culture plastic materials were from Greiner (Frickenhausen, Germany) or Sarstedt (Nümbrecht, Germany). To induce MICA expression, the melanoma cells were cultured in DMEM with $10 \mu \mathrm{M}$ of the histone deacetylase (HDAC) inhibitor suberoylanilide hydroxyamic acid (SAHA) (Qbiogene-Alexis, Grünberg, Germany) $20 \mathrm{~h}$ before being used for experiments. The pCMV6-AC-MICA-129Met or pCMV6-AC-MICA-129Val expression constructs and the L-MICA-129Met and LMICA-129Val cells have been described previously (Isernhagen et al. 2015). Malme cells were transfected with $50 \mu \mathrm{g}$ of $P v u \mathrm{I}$-linearized constructs by electroporation. After selection ( $1 \mathrm{mg} / \mathrm{ml} \mathrm{G} 418$, Biochrom, Berlin, Germany), clones (Malme-MICA-129Met and Malme-MICA-129Val) were obtained by limiting dilution.

\section{Genotyping}

One to five million cells were harvested, washed with phosphate-buffered saline (PBS), resuspended in $500 \mu$ lysis buffer (100 mM NaCl, 50 mM EDTA (pH 8.0), 10 mM Tris$\mathrm{HCl}(\mathrm{pH} 8.0), 0.5 \%$ sodium dodecyl sulfate, $0.1 \mathrm{mg} / \mathrm{ml}$ proteinase $\mathrm{K}, 20 \mu \mathrm{g} / \mathrm{ml} \mathrm{RNase} \mathrm{A}$ ), and incubated at $50^{\circ} \mathrm{C}$ shaking at 500 rounds per minute (rpm) overnight. Cell lysis was followed by phenol-chloroform extraction and alcohol precipitation using 2 volumes $100 \%$ ethanol and $1 / 10$ volume $5 \mathrm{M}$ lithium chloride. Genomic DNA was dissolved in $\mathrm{dH}_{2} \mathrm{O}$ or $8 \mathrm{mM} \mathrm{NaOH}$ and stored at $4{ }^{\circ} \mathrm{C}$. The SNP rs1051792 (G/A) leading to a substitution of $\operatorname{Val}(G)$ by $\operatorname{Met}(A)$ at position 129 of MICA was genotyped by a TaqMan assay (Applied Biosystems, Foster City, CA, USA) containing the forward primer 5'-GCTCTTCCTCTCCCAAAACCT-3' and the reverse primer $5^{\prime}$-CGTTCATGGCCAAGGTCTGA-3' and the two allele-specific dye-labeled probes FAM-5'A A T GGACAGTGCCCC- $3^{\prime}$ and VIC-5' AATGGACAATGCCCC-3'. Results were confirmed by Sanger sequencing, if required.

\section{Flow cytometry}

Flow cytometry was performed with a FACSCalibur ${ }^{\mathrm{TM}}$ flow cytometer and CellQuestPro ${ }^{\mathrm{TM}}$ software (BD Biosciences, Heidelberg, Germany). Cell surface expression of MICA on propidium iodide negative melanoma and mouse $\mathrm{L}$ cells was examined using the anti-MICA monoclonal antibody $(\mathrm{mAb})$ AMO1 (Bamomab, Gräfelfing, Germany); $10^{6}$ cells were incubated with $1 \mu \mathrm{g} \mathrm{mAb}$ in $100 \mu \mathrm{l}$ PBS for $45 \mathrm{~min}$. After washing with PBS, $1 \mu \mathrm{l}$ of the fluorescein isothiocyanate (FITC)-conjugated goat anti-mouse IgG Ab (155-095-062, Jackson Laboratories, via Dianova, Hamburg, Germany) was applied in $100 \mu \mathrm{l}$ PBS for $30 \mathrm{~min}$ as secondary reagent. MICA expression on all other human tumor cells was determined with an allophycocyanin (APC)-conjugated MICA antibody (clone 159227, mouse $\operatorname{IgG}_{2 b}$ R\&D Systems, Wiesbaden, Germany) compared to an isotype-matched control antibody. All stainings were done at $4{ }^{\circ} \mathrm{C}$ in the dark.

\section{Confocal microscopy}

Confocal microscopy was performed with Malme cells that were grown to sub-confluence (70 to $80 \%$ ) on acid-washed glass coverslips. After washing with PBS, cells were fixed and permeabilized with ice-cold methanol acetone solution (7:3) for $15 \mathrm{~min}$ at $-20{ }^{\circ} \mathrm{C}$. Cells were air dried and subsequently incubated with a blocking solution $(0.5 \%$ bovine serum albu$\min$ in PBS) for $1 \mathrm{~h}$ at room temperature. Subsequently, the 
cells were covered with $50 \mu \mathrm{l}$ of the primary antibody antiMICA (AMO1; $1 \mathrm{mg} / \mathrm{ml}$ ) diluted in 1:50 blocking solution, and incubated overnight at $4{ }^{\circ} \mathrm{C}$ in a humidified atmosphere. After washing five times with PBS, $1 \mu \mathrm{l}$ of the secondary Cy2-conjugated goat anti-mouse antibody (115-225-062, Jackson Laboratories, via Dianova, Hamburg, Germany) diluted in $100 \mu$ l blocking solution plus $1 \mu$ l of Hoechst 33342 $(10 \mathrm{mg} / \mathrm{ml})$ was added to the cells before incubation for 1 hour at room temperature. The coverslips were washed five times with PBS before they were mounted on microscope slides using fluorescence mounting medium (Dako, Hamburg, Germany). Microscopy was performed with the Zeiss LSM 510 Axioplan 2 confocal microscope.

\section{Enzyme-linked immunosorbent assay (ELISA)}

Concentrations of sMICA in the supernatants of cells $\left(10^{6}\right.$ cells, $10 \mathrm{ml}$ medium, $24 \mathrm{~h}$ ) and of intracytoplasmic (ic) MICA in cell lysates in relation to the total protein content were determined using the human MICA DuoSet (R\&D Systems). These assays were performed according to the manufacturer's protocols. All samples were analyzed in duplicate in comparison to a standard curve of MICA.

\section{Sodium dodecyl sulfate polyacrylamide gel electrophoresis (SDS-PAGE) and immunoblotting}

For Western blot analysis, the cells were lysed in $25 \mu \mathrm{l}$ Nonidet P-40 buffer $(1 \%)$ before $25 \mu$ l reducing loading buffer was added. After incubation for $4 \mathrm{~min}$ at $95{ }^{\circ} \mathrm{C}$, the lysates were loaded on $10 \%$ SDS gels for electrophoresis at 40 to $100 \mathrm{~V}$ for approximately $3 \mathrm{~h}$. Then the proteins were blotted onto a nitrocellulose membrane (Roth, Karlsruhe, Germany) for $1 \mathrm{~h}$ using a semi-dry blotting technique $(1 \mathrm{~mA} /$ $\left.\mathrm{cm}^{2}\right)$. The membrane was blocked in Tris-buffered saline with $0.1 \%$ Tween-20 (TBS-T) with $5 \%(w / v)$ non-fat dry milk for $1 \mathrm{~h}$, washed, and then incubated with a biotinylated antiMICA Ab $(0.4 \mu \mathrm{g} / \mathrm{ml}$, polyclonal goat IgG, BAF1300, R\&D Systems) and an anti- $\beta$-actin mAb (1:10,000, mouse $\operatorname{IgG}_{1}$, clone AC-15, Sigma-Aldrich) in TBS-T together with $5 \%(w / v)$ non-fat dry milk overnight at $4{ }^{\circ} \mathrm{C}$. After being washed three times for $10 \mathrm{~min}$ in TBS-T, the membrane was incubated with horseradish peroxidase (HRP)-conjugated streptavidin (1:2000, BioLegend, Fell, Germany) and HRP-labeled goat-anti-mouse IgG secondary $\mathrm{Ab}(1: 10,000,115-035-003$, Jackson Laboratories, via Dianova, Hamburg, Germany). Detection was done using an enhanced chemiluminescence (ECL) kit (GE Healthcare), and chemiluminescence was measured using a digital image acquisition system (Intas Chemilux Entry, Intas, Göttingen, Germany).

\section{Quantitative polymerase chain reaction (qPCR)}

Total RNA extraction and complementary DNA (cDNA) synthesis were carried out as described previously (Dressel et al. 2009). For MICA, the following forward and reverse primers were generated (5'- ACT TGA CAG GGA ACG GAA AGG A $-3^{\prime}$ and $5^{\prime}$ - CCA TCG TAG TAG AAA TGC TGG GA - $3^{\prime}$ ). The messenger RNA (mRNA) expression of the housekeeping gene glyceraldehyde 3-phosphate dehydrogenase $(G A P D H)\left(5^{\prime}-\right.$ ACG AAT TTG GCT ACA GCA ACA GGG $-3^{\prime}$ and $5^{\prime}$ - TCT ACA TGG CAA CTG TGA GGA GG $-3^{\prime}$ ) for human cell lines or hypoxanthine guanine phosphoribosyl transferase 1 (Hprt1) (5'- GTC CTG TGG CCA TCT GCC TA- $3^{\prime}$ and 5'- GGG ACG CAG CAA CTG ACA TT- 3') for mouse $\mathrm{L}$ cells were always monitored as internal control. Amplification reactions were carried out in 96-well plates in $25 \mu \mathrm{l}$ reaction volumes with the Power SYBR ${ }^{\circledR}$ green PCR master mix (Applied Biosystems, Foster City, USA). The PCR reaction plates were preheated for $2 \mathrm{~min}$ at $50^{\circ} \mathrm{C}$ and for $10 \mathrm{~min}$ at $95^{\circ} \mathrm{C}$ followed by 40 cycles of denaturation $\left(15 \mathrm{~s}\right.$ at $\left.95^{\circ} \mathrm{C}\right)$ and amplification $\left(1 \mathrm{~min}\right.$ at $\left.60{ }^{\circ} \mathrm{C}\right)$. All reactions were performed in technical triplicates using an ABI 7500 Real-Time PCR System. For the data analysis, the ABI 7500 SDS software (Applied Biosystems) was used. The variations in cDNA concentration in different samples were normalized to the housekeeping genes GAPDH or Hprt1. The cycle threshold (ct) values obtained for the target gene (tg), i.e., MICA, were corrected by the ct value obtained for the housekeeping gene $(\mathrm{hkg})$ in the same sample. The relative amount of transcripts was then expressed as $\Delta \mathrm{ct}$ value (ct for hkg minus ct for tg).

\section{Statistics}

The data were evaluated with SPSS (IBM, Ehningen, Germany) or WinStat software (R. Fitch Software, Bad Krozingen, Germany). Pearson correlation and $t$ tests were employed after confirming normal distribution of the data.

\section{Results}

Correlation of MICA expression and shedding in various tumor and melanoma cell lines with the $M I C A-129$ genotype

We analyzed the expression of MICA on the plasma membrane (pmMICA) in a panel of 16 human tumor cell lines of different entities (Fig. 1a). Whereas only one cell line was homozygous for MICA-129Met, nine cell lines were heterozygous and six cell lines homozygous for the MICA-129Val allele. Cell lines carrying the MICA-129Val/Val genotype showed a trend to have higher pmMICA expression intensities than those carrying one or two MICA-129Met alleles $(P=$ 

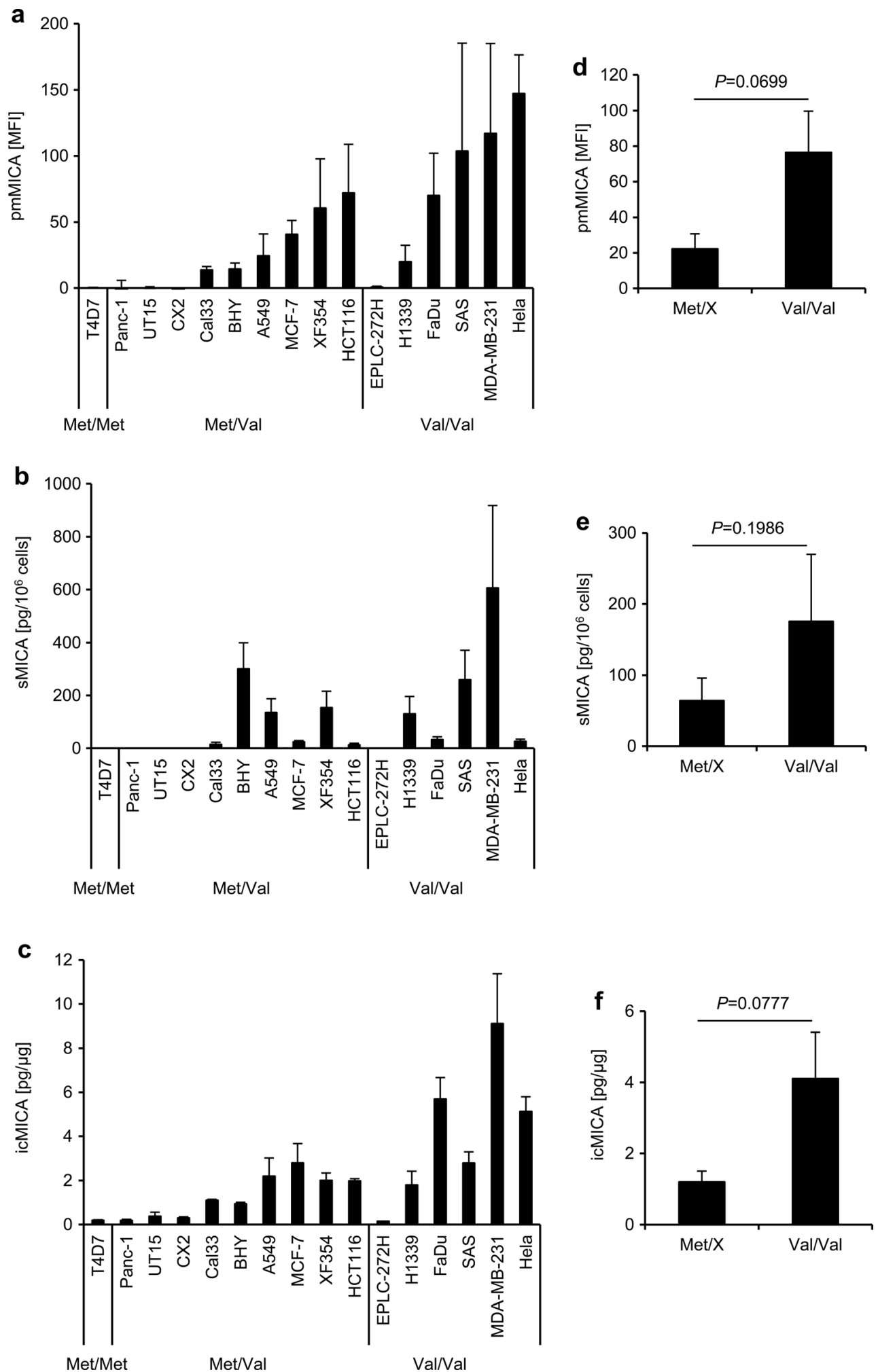

Fig. 1 MICA expression on the plasma membrane and release of sMICA in human tumor cell lines with different MICA-129 genotypes. a The expression of pmMICA on human tumor cell lines carrying the different MICA-129 genotypes (Met/Met, Met/Val, and Val/Val) was analyzed by flow cytometry. The mean fluorescence intensities (MFI) of pmMICA are displayed as means plus standard deviation $(S D)(n \geq$ 5). b In parallel, the amounts of soluble MICA ( $S M I C A)$ in the supernatants were determined by ELISA and are shown as means plus
SD of sMICA (pg/ $10^{6}$ cells). c The intracellular MICA (icMICA) was determined by ELISA and is shown as means plus SD. $\mathbf{d}-\mathbf{f}$ The data were grouped according to the MICA-129 genotype, and cell lines carrying one or two MICA-129Met alleles (Met/X, i.e., Met/Met and Met/Val) were compared to cell lines which were homozygous for the MICA-129Val allele. The data are shown as means plus standard error of the mean $(S E M)$ and they were analyzed by $t$ tests 
$0.0699, t$ test) (Fig. 1d). To determine the effect of the MICA129 dimorphism on shedding of MICA, the amount of sMICA in the supernatant of the cell lines cultured for $24 \mathrm{~h}$ was determined in parallel (Fig. 1b). The expression of pmMICA and release of sMICA did not strictly correlate. Hela cells, having on average the highest amounts of pmMICA, hardly released any sMICA. However, overall MICA-129Val homozygous cell lines appeared to release more sMICA although this trend was not statistically significant $(P=0.1986, t$ test) (Fig. 1e). Cell lines carrying the MICA-129Val/Val genotype appeared to have higher amounts of intracellular MICA (icMICA) as determined by ELISA (Fig. 1c) than those carrying one or two MICA-129Met alleles (Fig. 1f, borderline significant $P=$ $0.0777, t$ test).
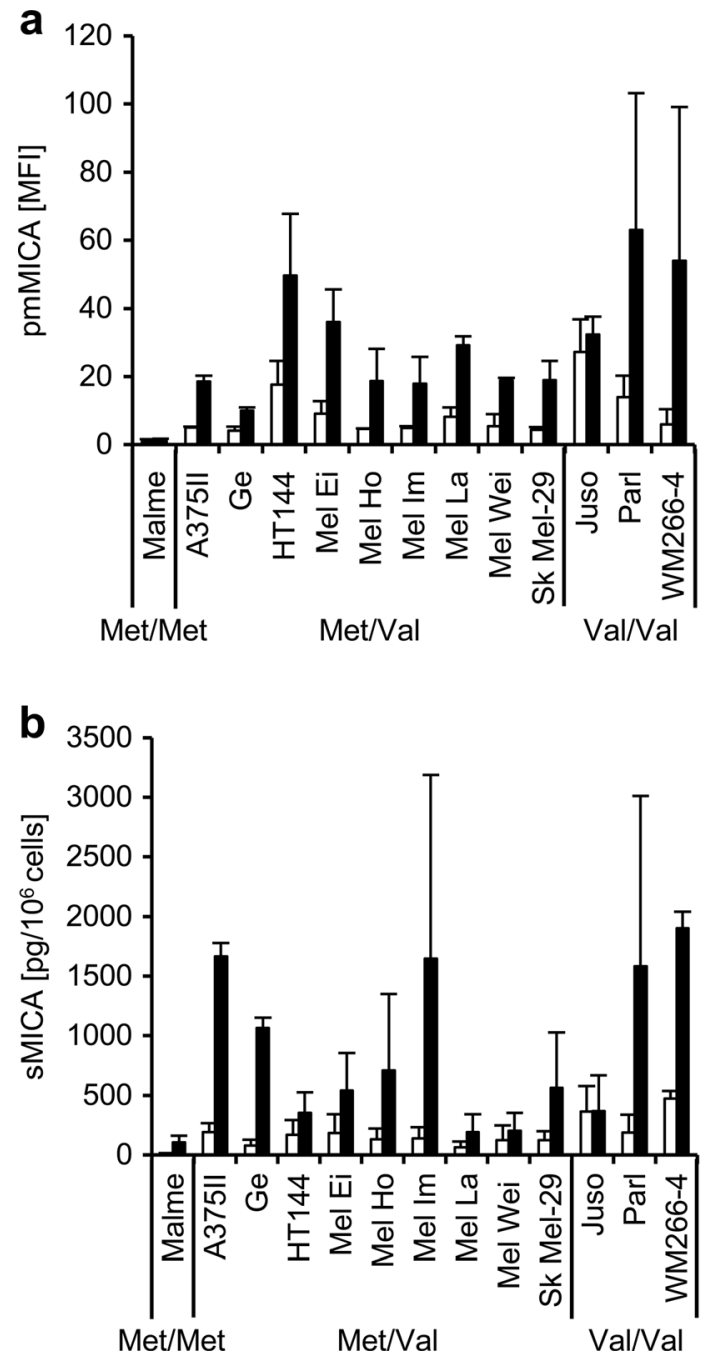

Fig. 2 MICA expression on the plasma membrane and release of sMICA in human melanoma cell lines with different MICA-129 genotypes. a The pmMICA expression of human melanoma cell lines carrying the different MICA-129 genotypes (Met/Met, Met/Val, and Val/Val) was analyzed by flow cytometry in control cells $(-S A H A)$ and cells treated with the HDAC inhibitor SAHA $(10 \mu \mathrm{M})$ for $20 \mathrm{~h}$ before analysis $(+S A H A)$. The MFI of pmMICA is shown as means plus $\mathrm{SD}(n \geq 3)$. $\mathbf{b}$ In parallel, the amounts of
Since the variations in MICA expression and release were high in this panel of tumor cell lines of different entities, we next investigated the MICA expression in a collection of 13 melanoma cell lines. One melanoma cell line was homozygous for MICA-129Met, nine were heterozygous, and three were homozygous for the MICA-129Val allele (Fig. 2a). The MICA plasma membrane expression intensity was on average significantly higher in the melanoma cell lines carrying a $M I-$ CA-129Val/Val genotype than in those which carried one or two MICA-129Met alleles ( $P=0.0429, t$ test) (Fig. 2c). Since the MICA expression was in general low on the melanoma cell lines, we induced MICA expression by adding the HDAC inhibitor SAHA for $20 \mathrm{~h}$ to the cell culture medium (Elsner et al. 2010; Elsner et al. 2007; Skov et al. 2005) (Fig. 2a). The

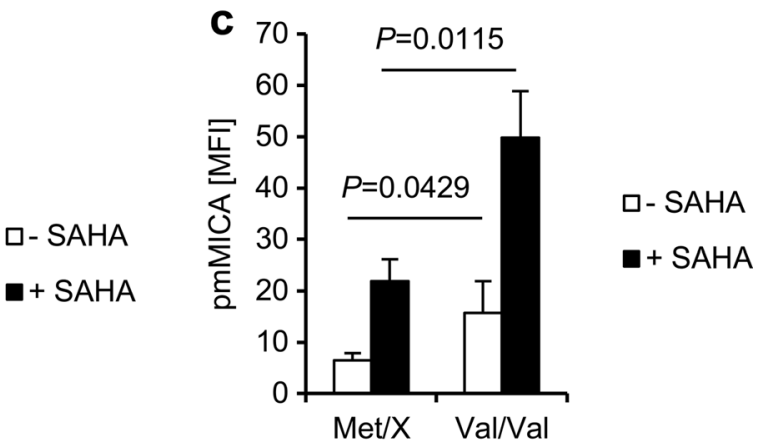

口- SAHA

- SAHA

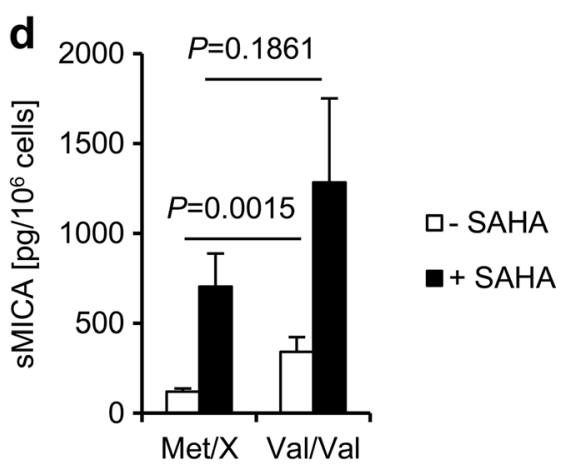

soluble MICA ( $S M I C A)$ in the supernatants were determined by ELISA and are shown as means plus SD of sMICA (pg/10 6 cells). d, e The data were grouped according to the MICA-129 genotype, and cell lines carrying one or two MICA-129Met alleles (Met/X, i.e., Met/Met and $\mathrm{Met} / \mathrm{Val}$ ) were compared to cell lines which were homozygous for the MICA-129Val allele. The data are displayed as means plus SEM, and they were analyzed by $t$ tests 
cell surface expression of MICA increased in all melanoma cell lines except Malme, which remained negative for pmMICA even after treatment with SAHA (Fig. 2a). The density of pmMICA was again significantly higher on the MICA-129Val homozygous melanoma cell lines than on those which carried one or two MICA-129Met alleles $(P=0.0115, t$
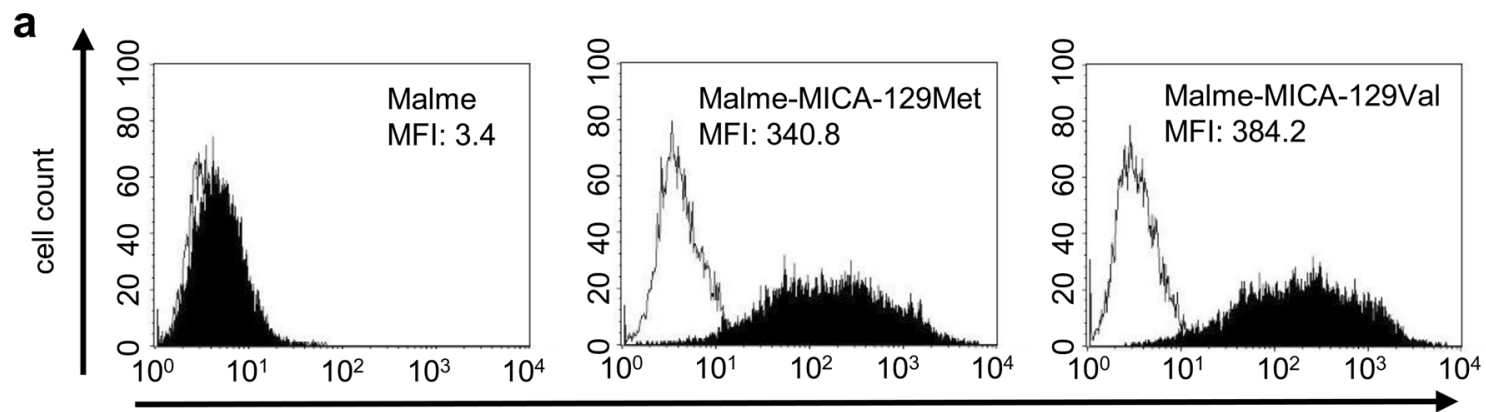

MICA [fluorescence intensity]
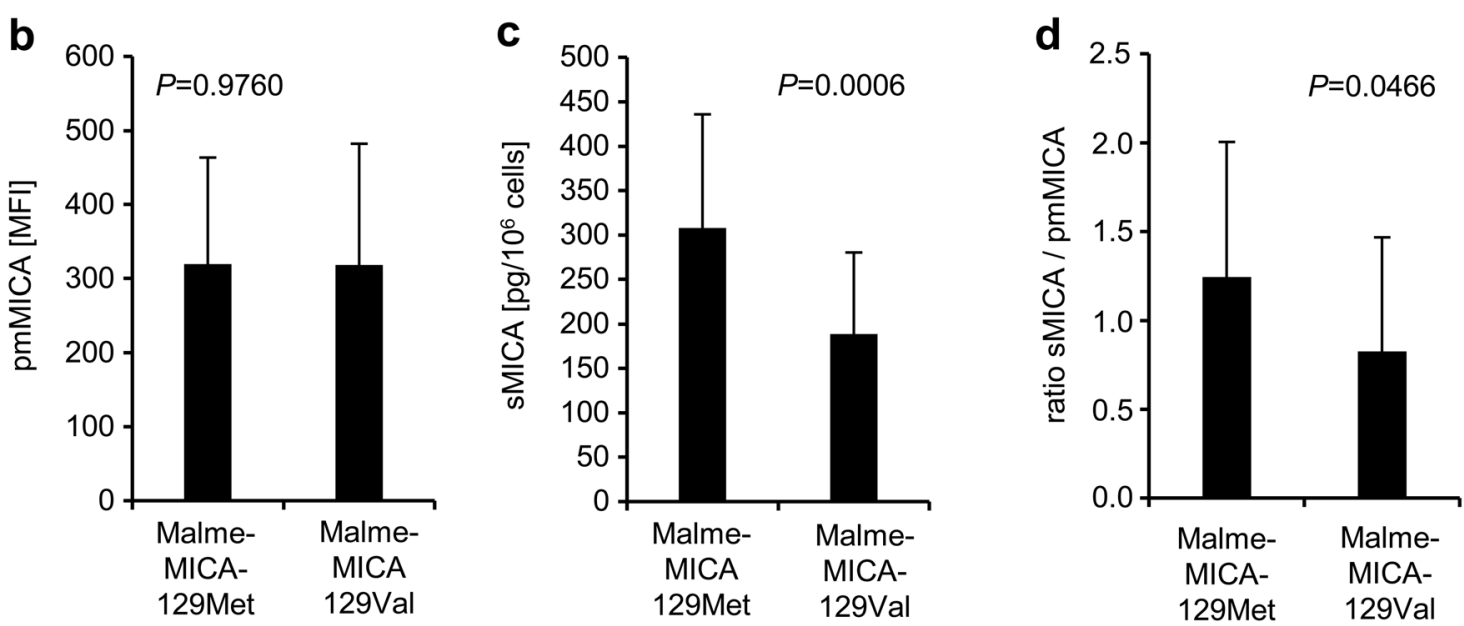

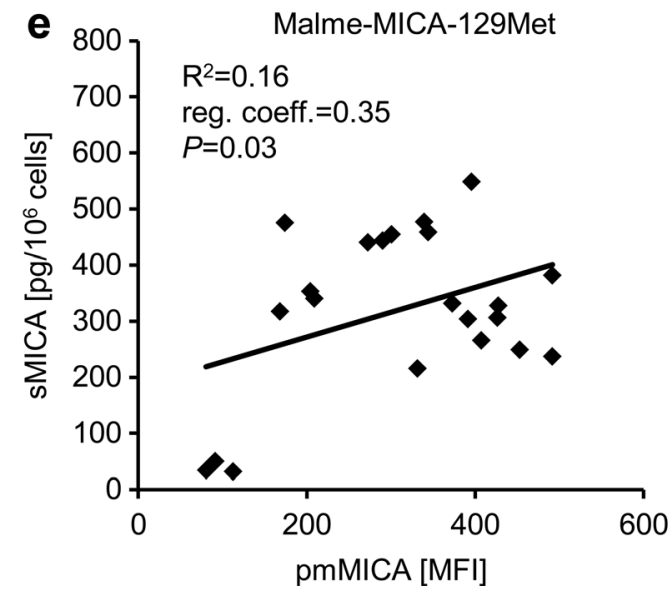

Fig. 3 MICA shedding in Malme cells expressing the MICA-129Met or MICA-129Val variants. a The pmMICA expression intensity was determined by flow cytometry as exemplified for a Malme-MICA129Met and a Malme-MICA-129Val clone and compared to parental Malme cells. The white histograms indicate cells stained with the secondary $\mathrm{Ab}$ only; the black histograms show the staining with antiMICA plus secondary Ab. b A summary of pmMICA expression intensity (mean+SD) on Malme-MICA-129Met $(n=22)$ and Malme-

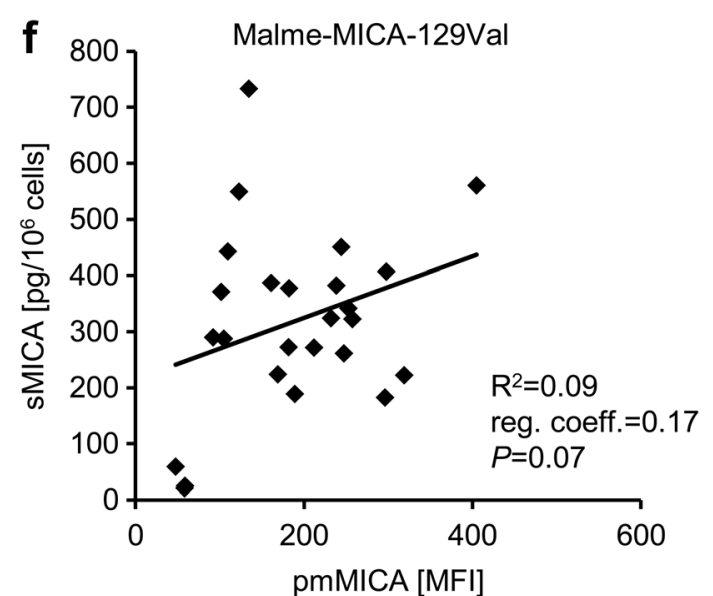

MICA-129Val clones $(n=25)$ is displayed. $\mathbf{c}$ In parallel, the amount of sMICA in the supernatant was determined by ELISA (pg/10 $10^{6}$ cells). d The ratios of sMICA/pmMICA were calculated. The data in $\mathbf{b}, \mathbf{c}$, and $\mathbf{d}$ were compared by a $t$ test. e The linear regressions of sMICA and pmMICA were determined for the Malme-MICA-129Met and $\mathbf{f}$ MalmeMICA-129Val clones. The coefficient of determination $\left(R^{2}\right)$, the regression coefficient (reg. coeff.), which is slope of the regression line, and the $P$ value (for the Pearson correlation) are indicated for both MICA variants 
test) (Fig. 2c). The spontaneous release of sMICA was low in all melanoma cell lines but increased after treatment with SAHA (Fig. 2b). Melanoma cell lines carrying a MICA$129 \mathrm{Val} / \mathrm{Val}$ genotype released significantly more sMICA than those which carried one or two MICA-129Met alleles $(P=$ $0.0015, t$ test) (Fig. 2d). However, after SAHA treatment, the difference in the amounts of sMICA did not reach statistical significance $(P=0.1861, t$ test) (Fig. 2d).

\section{Expression of the MICA-129Met/Val isoforms in the MICA-deficient human melanoma cell line Malme}

To clarify whether MICA shedding is directly affected by the MICA-129 genotype, the pmMICA-deficient melanoma cell line Malme was selected for further experiments. We had previously cloned the $M I C A^{*} 00701$ allele, which contains a methionine (Met) at amino acid position 129 (pCMV6-AC-MICA-129Met), and generated the MICA-129Val variant of the $M I C A^{*} 00701$ allele, which contains a valine (Val) at this position (pCMV6-AC-MICA-129Val) by site-directed mutagenesis (Isernhagen et al. 2015). Malme cells were transfected with these expression constructs and several clones expressing the MICA-129Met or MICA-129Val variants obtained by limiting dilution. Representative flow cytometry histograms for Malme wild-type cells and clones expressing the MICA129Met and MICA-129Val variant are displayed in Fig. 3a. A broad range of pmMICA expression intensities were observed within (Fig. 3a) and between different clones (Fig. 3b) but on average, the expression was similar on Malme-MICA-129Met and Malme-MICA-129Val clones $(P=0.9760, t$ test $)$.

\section{Effect of the MICA-129 dimorphism on shedding of MICA}

The shedding of MICA was then analyzed in parallel to pmMICA expression intensity of MICA in these clones. Notably, the amount of sMICA in the supernatant of these cells (Fig. 3c) was higher for cells transfected with the MICA129 Met variant $(P=0.0006, t$ test). Accordingly, also the ratio of sMICA and pmMICA expressions (Fig. 3d) was higher for the Malme-MICA-129Met than Malme-MICA-129Val clones ( $P=0.046, t$ test). Moreover, the amount of sMICA in the supernatant was partly dependent on pmMICA expression intensity for Malme-MICA-129Met cells as indicated by the coefficient of determination $\left(R^{2}=0.16\right)$ (Fig. 3e) but even less for Malme-MICA-129Val cells $\left(R^{2}=0.09\right)$ (Fig. 3f). These results suggested that the MICA-129Met/Val dimorphism directly influences MICA shedding and that the MICA-129Met variant is more susceptible to shedding than the MICA-129Val isoform. This result was not expected in view of the data obtained from non-transgenic tumor cell lines, in which we observed a higher pmMICA expression and a higher release of
sMICA in cell lines with the MICA-129 Val/Val genotype. Therefore, we speculated that the polymorphism could also directly affect pmMICA expression intensity and thereby control the release of sMICA.

\section{The MICA-129 dimorphism affects the MICA expression at the plasma membrane}

Immunofluorescence staining of MICA was performed to compare the subcellular expression pattern of the MICA129Met and the MICA-129Val isoforms in the Malme clones. Both MICA variants were found on the plasma membrane but also in intracellular compartments. A larger proportion of the MICA-129Met than the MICA-129Val variant appeared to be localized intracellularly (Fig. 4a-d). To quantify this distribution, we measured in parallel pmMICA by flow cytometry (Fig. 4e) and icMICA in cellular lysates by ELISA (Fig. 4f) and Western blot (Fig. 4j) in 11 clones of each genotype. Again, the expression of pmMICA was overall similar in Malme-129Met and Malme-129Val clones ( $P=0.3844, t$ test) (Fig. 4e). However, significantly more icMICA was found in the Malme-129Met than in Malme-129Val clones by ELISA ( $P=0.0199, t$ test) (Fig. 4f). Notably, the amount of icMICA increased with the pmMICA expression intensity for MalmeMICA-129Met clones (regression coefficient $=0.09, R^{2}=$ 0.24) (Fig. 4g) but not for Malme-MICA-129Val clones (regression coefficient $=-0.01, R^{2}=0.05$ ) (Fig. 4h). Furthermore, cellular lysates of these clones were tested by Western blot for MICA expression as illustrated in Fig. 4i. Densitometry of MICA in comparison to $\beta$-actin (Fig. 4j) indicated a higher

Fig. 4 MICA expression on the plasma membrane and in intracellular compartments of Malme cells expressing the MICA-129Met or MICA129 Val isoform. a Confocal microscopy images show pmMICA and icMICA in a Malme-MICA-129Met clone after staining with an antiMICA plus secondary Ab (green). Nuclei are stained with Hoechst 33342 (blue). The scale bar represents $10 \mu \mathrm{m}$. b The control illustrates the staining with the secondary Ab only. c A Malme-MICA-129Val clone is displayed after staining with an anti-MICA plus secondary Ab (green). d The control illustrates the staining with the secondary $\mathrm{Ab}$ only. e The pmMICA expression intensity on Malme-MICA-129Met $(n=11)$ and Malme-MICA-129Val clones $(n=11)$ is summarized as mean plus SD. The data were compared by a $t$ test. f In parallel, the amounts of intracellular MICA (icMICA) were determined by ELISA and are shown as means plus SD. The data were compared by a $t$ test. The linear regressions of icMICA and pmMICA are displayed for the $\mathbf{g}$ Malme-MICA-129Met and $\mathbf{h}$ Malme-MICA-129Val clones. The coefficient of determination $\left(R^{2}\right)$, the regression coefficient (reg. coeff.), and the $P$ value (for the Pearson correlation) are indicated for both MICA variants. i An immunoblot is shown on which lysates of five MalmeMICA-129Met clones, five Malme-MICA-129Val clones, and parental Malme cells were probed with anti-MICA and, as loading control, anti- $\beta$ actin Abs. The bands of a protein size marker are indicated at the left side. MICA bands are broad due to variations of glycosylation. $\mathbf{j}$ Immunoblots were analyzed by densitometry, and a summary of MICA $/ \beta$-actin ratios of Malme-MICA-129Met $(n=11)$ and Malme-MICA-129Val $(n=11)$ clones is displayed as means plus SD. The data were compared by a $t$ test 

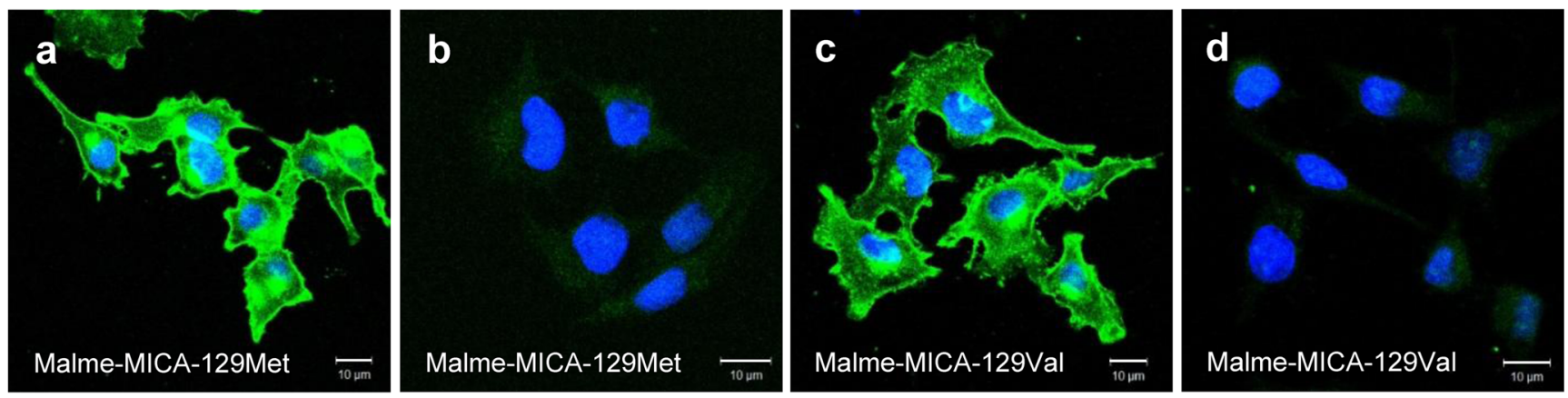

e

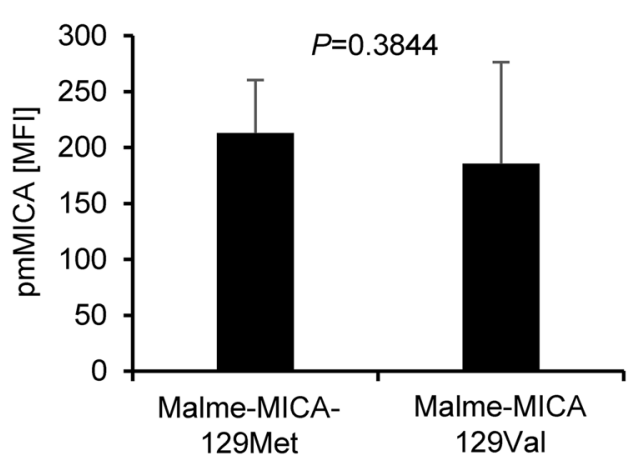

g

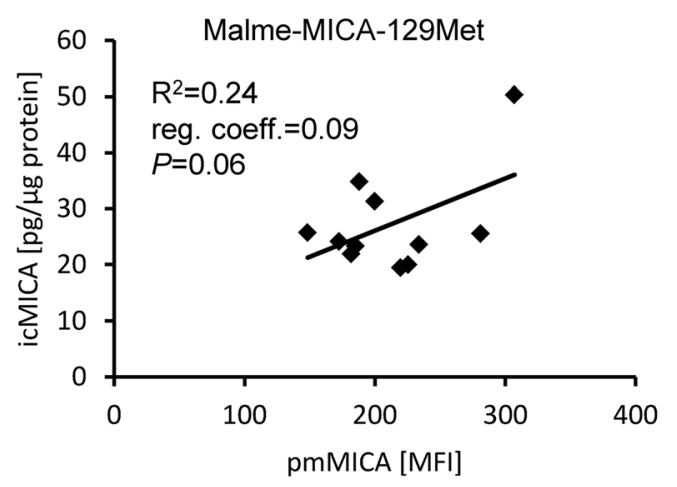

i

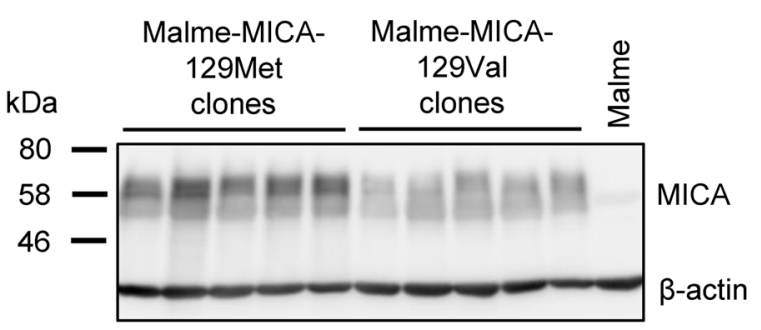

ratio of MICA/ $\beta$-actin in Malme-MICA-129Met than in Malme-MICA-129Val clones $\left(P=8.16 \times 10^{-7}\right)$. Together, these results indicated that a larger proportion of the MICA129 Met than the MICA-129Val variant was localized intracellularly.

f

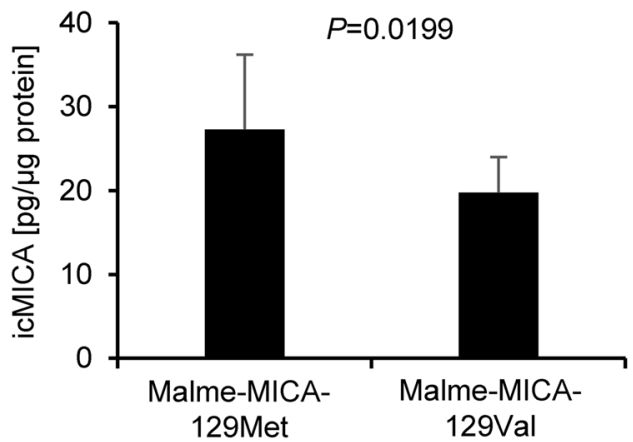

h
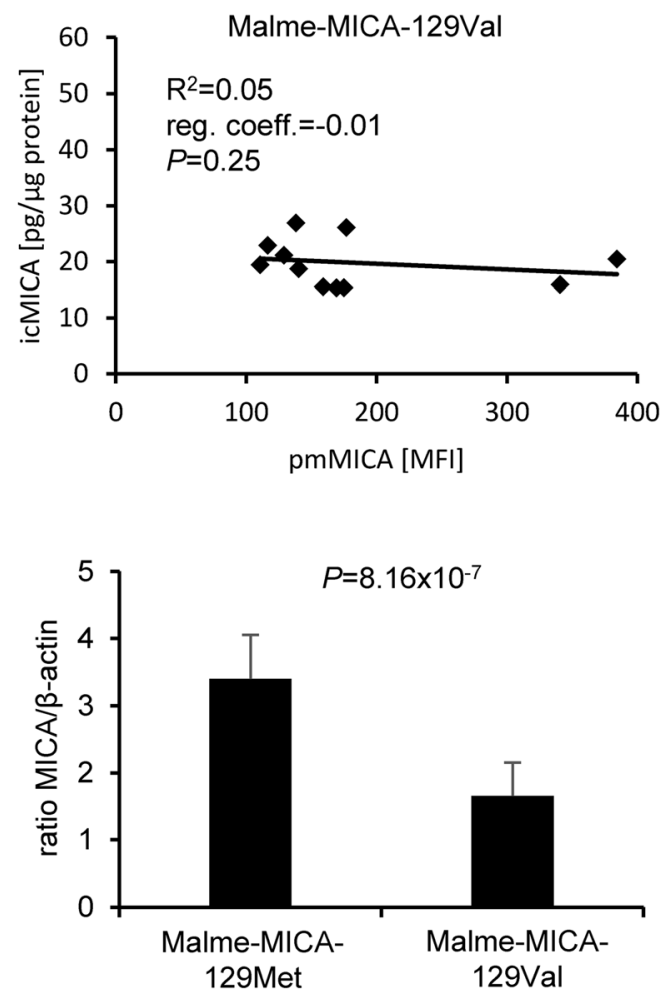

We then compared in parallel MICA mRNA and pmMICA expression in 17 Malme-129Met and 17 Malme-129Val clones. The pmMICA expression was again not significantly different in these experiments $(P=0.9522, t$ test $)$ (Fig. 5a), but more MICA mRNA was found in the Malme-129Met than 
Malme-129Val clones ( $P=0.0047, t$ test $)$ as indicated by lower $\Delta$ ct values (Fig. $5 b$ ). In both Malme-MICA-129Met and Malme-MICA-129Val clones, the MICA mRNA expression intensity correlated with the pmMICA expression intensity $\left(R^{2}=0.43\right.$ for Malme-MICA-129Met and $R^{2}=0.36$ for Malme-MICA-129Val clones) (Fig. 5c, d). Overall, the MICA mRNA expression correlated also with total MICA protein expression as determined by MICA $/ \beta$-actin ratio in Western blot $\left(R^{2}=0.25\right)$. However, since the clones had been selected for similar pmMICA expression intensities, both MICA mRNA and protein expression was higher for MalmeMICA-129Met than Malme-MICA-129Val clones (Fig. 5e).

To confirm the results obtained with the Malme clones, we also analyzed mouse fibroblast $\mathrm{L}$ cells, which previously had been transfected with the pCMV6-AC-MICA-129Met/Val expression constructs (Isernhagen et al. 2015). Murine cells do not have a MICA gene and from these L cells MICA was not released by shedding (Isernhagen et al. 2015). The MICA cell membrane expression of the $\mathrm{L}$ cell clones was on average similar between L-MICA-129Met and L-MICA-129Val clones (Fig. 6a) $(P=0.1848, t$ test). In line with the results obtained with Malme clones, the MICA mRNA expression (Fig. 6b) was also significantly higher (indicated by lower $\Delta$ ct values) in $\mathrm{L}$ cell clones expressing the MICA-129Met than the MICA129 Val variant $(P=0.0212, t$ test). The pmMICA expression intensity was weakly dependent on the mRNA expression intensity in clones transfected with the MICA-129Met variant as indicated by the coefficient of determination $\left(R^{2}=0.18\right)$ (Fig. 6c). However, for L cells expressing the MICA-129Val variant, the MICA mRNA and pmMICA expression intensities correlated tightly $\left(R^{2}=0.69\right)$ (Fig. 6d).

Taken together, the MICA-129Met/Val dimorphism appears to affect MICA plasma membrane expression intensity and shedding, and both processes together determine the extent of sMICA release.

\section{Discussion}

Numerous studies have identified MICA polymorphisms to be associated with various malignant and autoimmune diseases. In view of the biological function of MICA as a NKG2D ligand, these data suggest that $M I C A$ variants themselves could be causative for at least some of these associations despite linkage disequilibrium in the HLA region. The SNP (rs1051792) of the MICA gene resulting in the MICA129Met/Val dimorphism was the first MICA polymorphism for which a functional consequence was described. Steinle and colleagues identified the MICA-129Met variants as high and MICA-129Val variants as low avidity NKG2D ligands (Steinle et al. 2001). Recently, we investigated the functional consequences of this polymorphism in more detail (Isernhagen et al. 2015). Engagement of NKG2D on NK cells by the high-avidity MICA-129Met variant was characterized by stronger and faster NKG2D signaling resulting in more NK cell cytotoxicity and interferon- $\gamma$ release. On $\mathrm{CD} 8^{+} \mathrm{T}$ cells, the MICA-129Met variant mediated a faster co-stimulation and activated the cells in combination with limited CD3mediated signals. Notably, on both cell types, the MICA129Met variant induced also a rapid NKG2D downregulation. Therefore, the effects elicited by the MICA-129Met variant were not sustained and at high MICA expression intensities, the MICA-129Val variant elicited even more NKG2Dmediated responses, such as NK cell cytotoxicity, than the MICA-129Met variant.

Two recent studies suggested that the MICA-129Val/Val genotype was associated with higher sMICA serum levels in patients with ulcerative colitis (Zhao et al. 2011) as well as in patients with hepatitis B virus-induced hepatocellular carcinoma and healthy controls (Tong et al. 2013). It was unclear, however, whether the MICA-129 dimorphism has a direct effect on the generation of sMICA or is linked to other polymorphisms affecting MICA shedding. We were therefore interested to clarify whether the MICA-129Met/Val dimorphism not only directly affects NKG2D signaling but also MICA shedding.

We investigated pmMICA expression in parallel to release of sMICA in 16 tumor cell lines of various entities and 13 melanoma cell lines. The MICA plasma membrane expression intensities on the melanoma cell lines were higher on cell lines, which were homozygous for the MICA-129Val allele than on those which carried either one or two MICA-129Met alleles. Similarly, the amount of sMICA released from the melanoma cell lines carrying two MICA-129Val alleles was higher than from those which carried one or two MICA$129 \mathrm{Met}$ alleles. The panel of various tumor cell lines displayed the same trends. The two cell lines, which were homozygous for the MICA-129Met variant (Malme, melanoma and T47D, breast cancer), were both negative for pmMICA expression and released very little sMICA into the cell culture supernatant. The plasma membrane expression was not (Malme) or only slightly (T47D, data not shown) inducible by treatment with the HDAC inhibitor SAHA. Although these results suggested that the expression of MICA-129Met variants at the plasma membrane is lower and that MICA-129Met variants are less released by shedding than MICA-129Val variants, the number especially of MICA-129Met homozygous cell lines has been too low to draw definitive conclusions since MICA alleles can vary with respect to mRNA expression intensity (Shafi et al. 2011). Notably, some MICA alleles such as $M I C A^{*} 008$ can have various promoter variants (Cox et al. 2014), which might alter expression intensities.

Therefore, we transfected the MICA-negative melanoma cell line Malme with expression constructs for MICA which differed only at position 129 and obtained cell clones expressing both MICA variants at similar intensities. Malme-MICA129Met clones released more sMICA than Malme-MICA- 


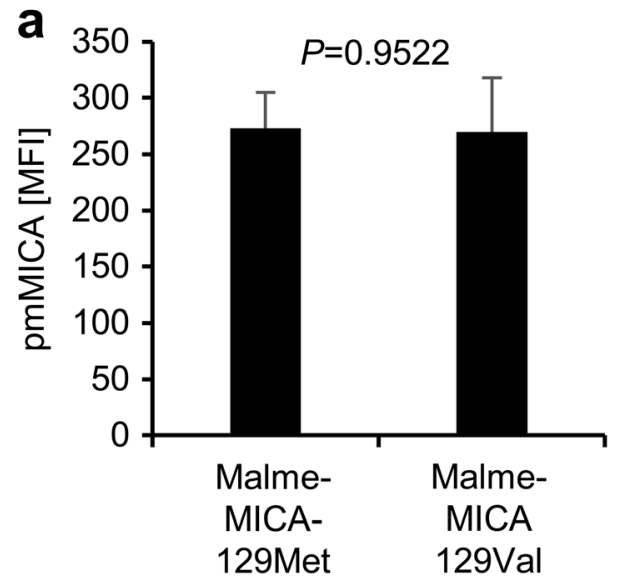

C

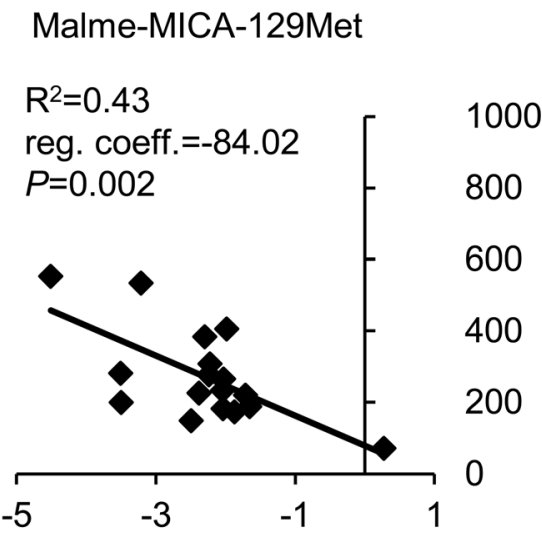

MICA mRNA expression $\left[\Delta \mathrm{ct}_{\mathrm{tg}-\mathrm{hkg}}\right]$

e

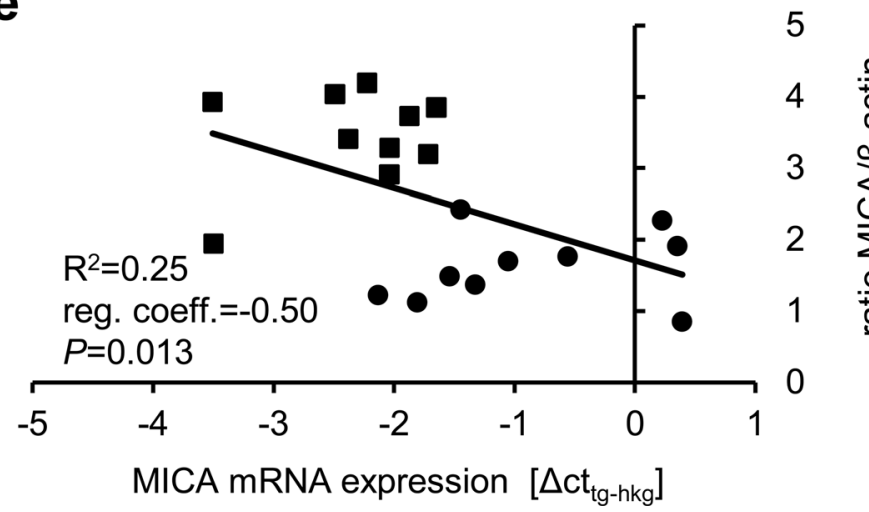

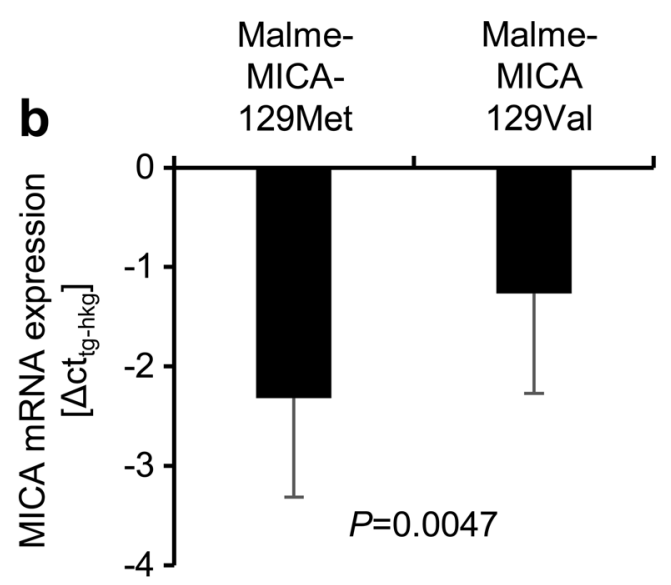

d

Malme-MICA-129Val

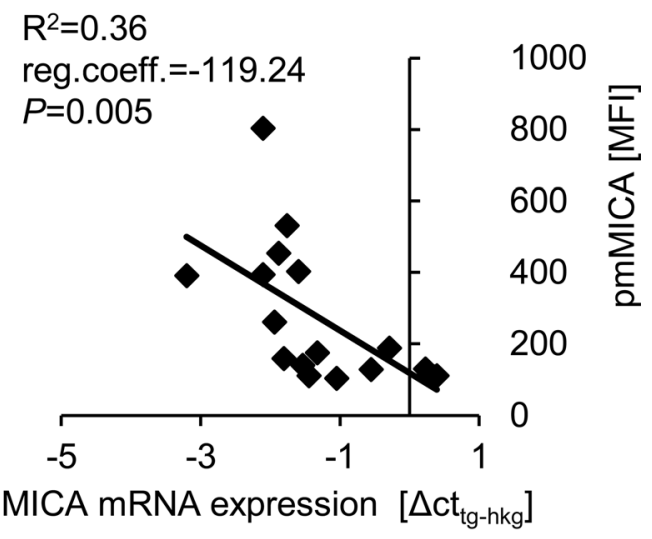

5

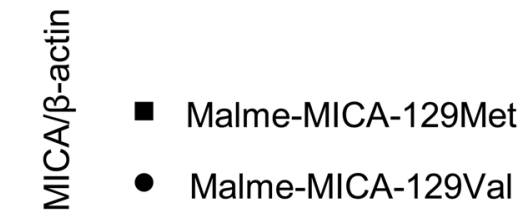

Fig. 5 Correlation of MICA mRNA and pmMICA expression intensity in Malme cells expressing the MICA-129Met and MICA-129Val variants. a The MFI of pmMICA expression was determined by flow cytometry on Malme-MICA-129Met $(n=17)$ and Malme-MICA-129Val $(n=17)$ clones. The data are summarized as means plus SD and were compared by a $t$ test. b In parallel, the MICA mRNA expression $\left(\Delta \mathrm{Ct}_{\mathrm{tg}}\right.$ $-\mathrm{hkg}$ ) was determined by qPCR. Expression values of the target gene ( $\mathrm{tg}$ ) $M I C A$ were calculated from means of technical triplicates after normalization to the housekeeping gene ( $h \mathrm{~kg}) \mathrm{GAPDH}$. The data are summarized as means plus SD and were compared by a $t$ test. It should be noted that lower $\Delta \mathrm{Ct}_{\mathrm{tg} \text {-hkg }}$ values indicate higher mRNA expression levels. The linear regressions of MICA mRNA expression and pmMICA expression are displayed for c Malme-MICA-129Met and d MalmeMICA-129Val clones. The coefficient of determination $\left(R^{2}\right)$, the regression coefficient (reg. coeff.), and the $P$ value (for the Pearson correlation) are indicated for both MICA variants. e The linear regression of MICA mRNA expression and total MICA expression as determined by Western blot is shown for Malme-MICA-129Met and Malme-MICA-129Val clones, in which mRNA and protein expression had been measured in parallel 


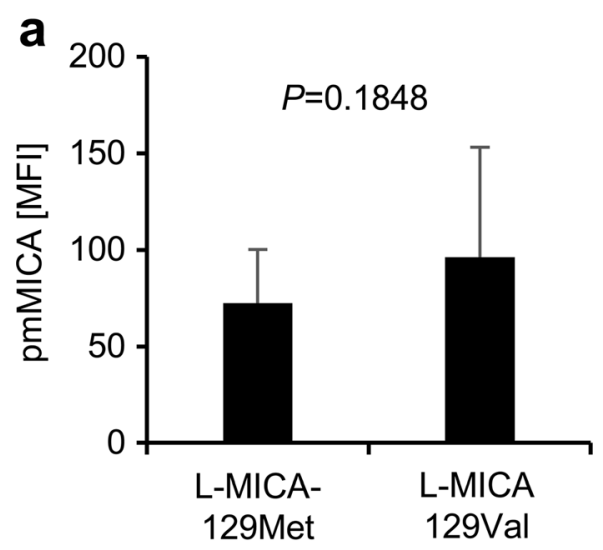

C

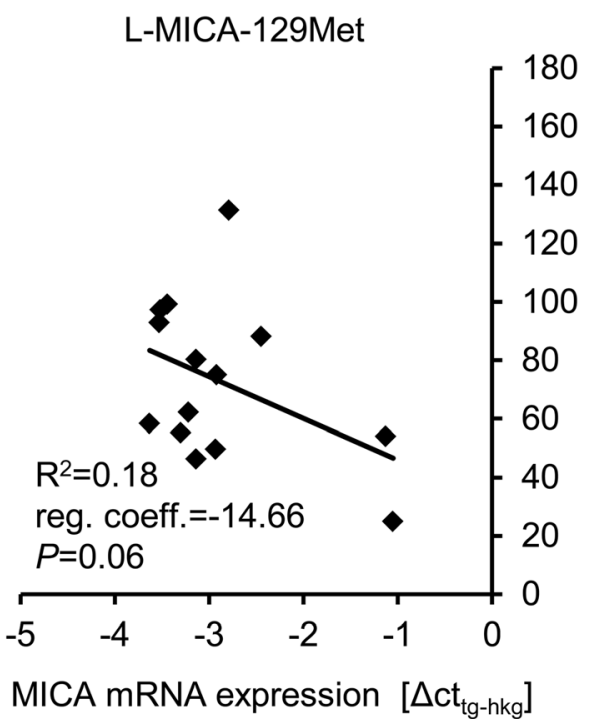

Fig. 6 Correlation of MICA mRNA and pmMICA expression intensity in L cells expressing the MICA-129Met and MICA-129Val variants. a The MFI of pmMICA expression was determined by flow cytometry on L-MICA-129Met $(n=14)$ and L-MICA-129Val $(n=12)$ clones. The data are summarized as means plus SD and were compared by a $t$ test. b In parallel, the MICA mRNA expression $\left(\Delta C \mathrm{t}_{\mathrm{tg}-\mathrm{hkg}}\right)$ was determined by qPCR. Expression values of the target gene $(\mathrm{tg}) \mathrm{MICA}$ were calculated from mean of technical triplicates after normalization to the housekeeping

129Val clones. This finding indicates that the MICA-129Met/ Val dimorphism does affect MICA shedding. The MICA$129 \mathrm{Met} /$ Val dimorphism is localized in the $\alpha 2$ domain, which is far away from the cleaving site in the stalk region. Therefore, it influences shedding likely indirectly by a conformational change affecting the accessibility of MICA for ADAM family proteases or the chaperone ERp5.

In contrast to this result, we found more sMICA in the supernatant of tumor and melanoma cell lines carrying a $M I$ CA-129Val/Val genotype. Notably, these cell lines expressed also more MICA on their plasma membrane. Therefore, we compared the expression pattern of MICA in the Malme transfectants. Both MICA variants were found at the plasma membrane in similar amounts, but in intracellular
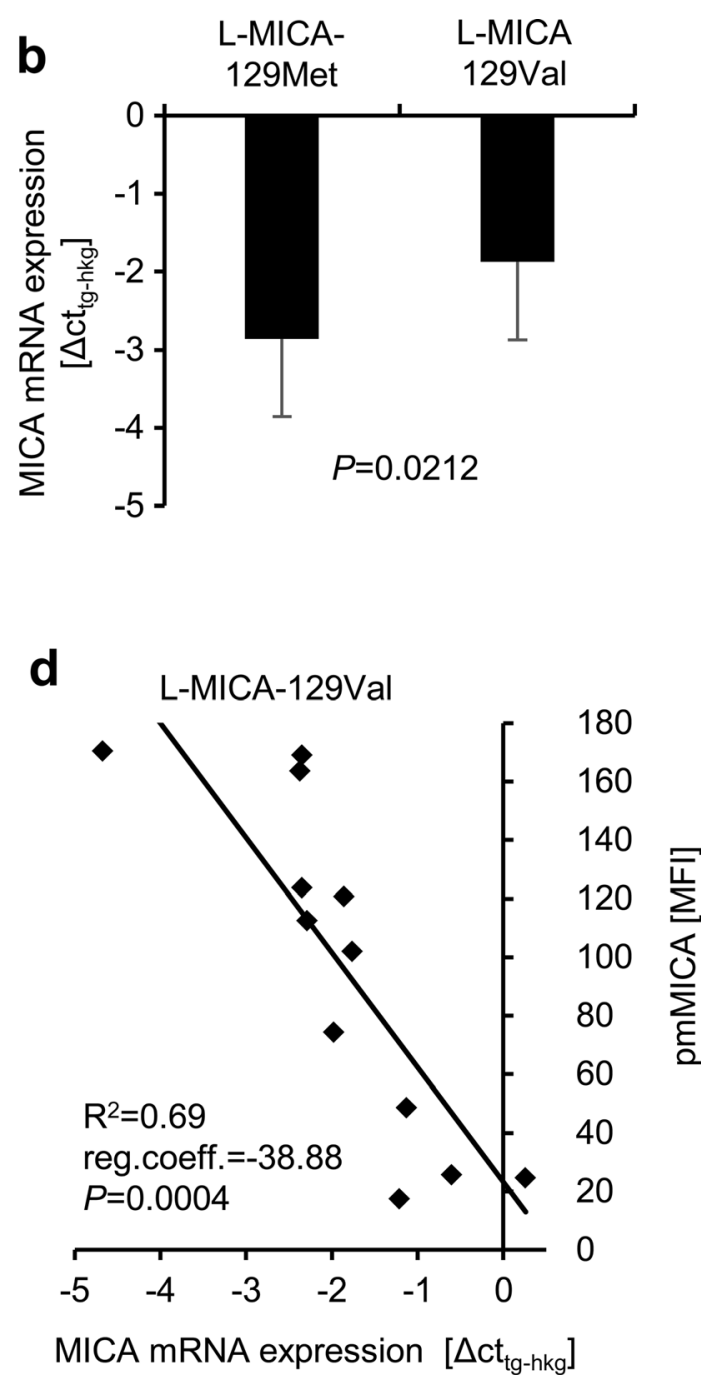

gene $(h \mathrm{~kg}) \mathrm{Hprt}$. The data are summarized as means plus SD and were compared by a $t$ test. It should be noted that lower $\Delta \mathrm{Ct}_{\mathrm{tg}-\mathrm{hkg}}$ values indicate higher mRNA expression levels. The linear regressions of MICA mRNA expression and pmMICA expression are displayed for $\mathbf{c}$ L-MICA-129Met and d L-MICA-129Val clones. The coefficient of determination $\left(R^{2}\right)$, the regression coefficient (reg. coeff.), and the $P$ value (for the Pearson correlation) are indicated for both MICA variants

compartments, more MICA was found in Malme cells expressing the MICA-129Met than the MICA-129Val variant. This result suggests that the MICA-129Met and MICA129Val variants either differ in the efficacy of transport to the cell surface, in recycling into intracellular compartment after expression at the plasma membrane, or in degradation after internalization. An alteration of the intracellular transport has been described previously for MICA-A5.1 variants (Ashiru et al. 2013). Moreover, it has been recently reported that the $\mathrm{N}$ glycosylation of asparagine 8 in MICA018 is important for cell surface expression of this variant (Mellergaard et al. 2014), but the MICA-129Met/Val dimorphism has previously not been implicated in the regulation of cell surface expression. 
As mentioned before, the cell clones were selected to have on average a similar pmMICA expression intensity. Nonetheless, the selected Malme-MICA-129Met clones expressed more MICA mRNA than Malme-MICA-129Val clones. Similarly, in mouse $\mathrm{L}$ cells which were transfected with the same constructs, more MICA-129Met than MICA-129Val mRNA was expressed in clones which had similar pmMICA expression intensities. The correlation of MICA mRNA and pmMICA expression appeared to be partly better for mouse L cells than for human MALME cells. This could be due to the failure of L cells to shed MICA (Isernhagen et al. 2015). Proteins involved in shedding of NKG2D ligands might not be expressed in L cells or fail to interact with human MICA. Moreover, other proteins which retain MICA-129Met variants in human cells could not be present or fail to interact with MICA in mouse cells.

Taken together, these results show that the MICA-129Met variant was less efficiently expressed at the plasma membrane than the MICA-129Val variant. A larger proportion of the MICA-129Met variant was in intracellular compartments. Whether this was due to alteration of transport, recycling or degradation remains to be elucidated. In Malme and L cells, more mRNA of the MICA-129Met than the MICA-129Val variant was required to obtain a similar pmMICA expression intensity.

The generation of sMICA can be affected by polymorphisms, which regulate cell surface expression, and polymorphisms, which alter the efficacy of cleavage by shedding proteases. Our results demonstrate that the MICA-129 dimorphism affects both processes leading to a reduced cell surface expression and an increased shedding of MICA-129Met variants. Both processes limit the cell surface expression of the high-avidity MICA-129Met variant, which causes a strong NKG2D counter-regulation, if present at high density and for prolonged time (Isernhagen et al. 2015). On the other hand, even low amounts of MICA-129Met signals can activate a strong and fast NKG2D signaling (Isernhagen et al. 2015). Therefore, both MICA-129 variants may confer advantages and disadvantages in certain situations, such as virus infections, suggesting balancing evolution of MICA alleles. The mechanisms by which the MICA-129 dimorphism affects plasma membrane expression and shedding need to be investigated further. Although the MICA-129Val variant was apparently less efficiently cleaved to produce sMICA, the higher plasma membrane expression intensity of MICA-129Val variants could explain the association of this variant with higher sMICA concentration in tumor cell culture supernatants as shown here or in patient sera as described previously by others (Tong et al. 2013; Zhao et al. 2011).

In conclusion, we have shown that the MICA-129 dimorphism directly affects plasma membrane expression and shedding and these functional effects might contribute to the numerous disease associations, which have been reported for this polymorphism.
Acknowledgments The authors would like to thank Christine Steffens for contributing to the initial transfection of Malme cells. This work was supported by the Deutsche Forschungsgemeinschaft (DFG) (GRK 1034, SFB 1002 TP C05, SFB 824/2 B4, INST 95/980-1 FUGG, INST 411/37-1 FUGG irradiation devices), the European Union grant FP7-PEOPLE-2012-ITN-315963 (CELLEUROPE), the Wilhelm Sander-Stiftung (2012.078.1), the Federal Ministry of Education and Research (BMBF) (Strahlenkompetenz, 03NUK038A, 02NUK031B, Innovative Therapies, 01GU0823, DKTK-ROG), and the DFG Cluster of Excellence: Munich-Centre for Advanced Photonics (MAP).

\section{Compliance with ethical standards}

Conflict of interest The authors declare that they have no competing interests.

Open Access This article is distributed under the terms of the Creative Commons Attribution 4.0 International License (http:// creativecommons.org/licenses/by/4.0/), which permits unrestricted use, distribution, and reproduction in any medium, provided you give appropriate credit to the original author(s) and the source, provide a link to the Creative Commons license, and indicate if changes were made.

\section{References}

Amroun H, Djoudi H, Busson M, Allat R, El Sherbini SM, Sloma I, Ramasawmy R, Brun M, Dulphy N, Krishnamoorthy R, Toubert A, Charron D, Abbadi MC, Tamouza R (2005) Early-onset ankylosing spondylitis is associated with a functional MICA polymorphism. Hum Immunol 66:1057-1061

Andre P, Castriconi R, Espeli M, Anfossi N, Juarez T, Hue S, Conway H, Romagne F, Dondero A, Nanni M, Caillat-Zucman S, Raulet DH, Bottino C, Vivier E, Moretta A, Paul P (2004) Comparative analysis of human NK cell activation induced by NKG2D and natural cytotoxicity receptors. Eur J Immunol 34:961-971

Ashiru O, Lopez-Cobo S, Fernandez-Messina L, Pontes-Quero S, Pandolfi R, Reyburn HT, Vales-Gomez M (2013) A GPI anchor explains the unique biological features of the common NKG2Dligand allele MICA*008. Biochem J 454:295-302

Ayo CM, de Oliveira AP, Camargo AV, Brandao de Mattos CC, Bestetti RB, de Mattos LC (2015) Association of the functional MICA-129 polymorphism with the severity of chronic Chagas heart disease. Clin Infect Dis 61:1310-1313

Bahram S, Bresnahan M, Geraghty DE, Spies T (1994) A second lineage of mammalian major histocompatibility complex class I genes. Proc Natl Acad Sci U S A 91:6259-6263

Billadeau DD, Upshaw JL, Schoon RA, Dick CJ, Leibson PJ (2003) NKG2D-DAP10 triggers human NK cell-mediated killing via a Syk-independent regulatory pathway. Nat Immunol 4:557-564

Boukouaci W, Busson M, Peffault de Latour R, Rocha V, Suberbielle C, Bengoufa D, Dulphy N, Haas P, Scieux C, Amroun H, Gluckman E, Krishnamoorthy R, Toubert A, Charron D, Socie G, Tamouza R (2009) MICA-129 genotype, soluble MICA, and anti-MICA antibodies as biomarkers of chronic graft-versus-host disease. Blood 114:5216-5224

Champsaur M, Lanier LL (2010) Effect of NKG2D ligand expression on host immune responses. Immunol Rev 235:267-285

Chen D, Juko-Pecirep I, Hammer J, Ivansson E, Enroth S, Gustavsson I, Feuk L, Magnusson PK, McKay JD, Wilander E, Gyllensten U 
(2013) Genome-wide association study of susceptibility loci for cervical cancer. J Natl Cancer Inst 105:624-633

Chitadze G, Bhat J, Lettau M, Janssen O, Kabelitz D (2013) Generation of soluble NKG2D ligands: proteolytic cleavage, exosome secretion and functional implications. Scand J Immunol 78:120-129

Choy MK, Phipps ME (2010) MICA polymorphism: biology and importance in immunity and disease. Trends Mol Med 16:97-106

Clayton A, Mitchell JP, Court J, Linnane S, Mason MD, Tabi Z (2008) Human tumor-derived exosomes down-modulate NKG2D expression. J Immunol 180:7249-7258

Cox ST, Madrigal JA, Saudemont A (2014) Diversity and characterization of polymorphic $5^{\prime}$ promoter haplotypes of MICA and MICB genes. Tissue Antigens 84:293-303

Douik H, Ben Chaaben A, Attia Romdhane N, Romdhane HB, Mamoghli T, Fortier C, Boukouaci W, Harzallah L, Ghanem A, Gritli S, Makni M, Charron D, Krishnamoorthy R, Guemira F, Tamouza R (2009) Association of MICA-129 polymorphism with nasopharyngeal cancer risk in a Tunisian population. Hum Immunol 70:45-48

Dressel R, Johnson JP, Günther E (1998) Heterogeneous patterns of constitutive and heat shock induced expression of HLA-linked HSP701 and HSP70-2 heat shock genes in human melanoma cell lines. Melanoma Res 8:482-492

Dressel R, Guan K, Nolte J, Elsner L, Monecke S, Nayernia K, Hasenfuss G, Engel W (2009) Multipotent adult germ-line stem cells, like other pluripotent stem cells, can be killed by cytotoxic $\mathrm{T}$ lymphocytes despite low expression of major histocompatibility complex class I molecules. Biol Direct 4:31

El-Gazzar A, Groh V, Spies T (2013) Immunobiology and conflicting roles of the human NKG2D lymphocyte receptor and its ligands in cancer. J Immunol 191:1509-1515

Elsner L, Muppala V, Gehrmann M, Lozano J, Malzahn D, Bickeböller H, Brunner E, Zientkowska M, Herrmann T, Walter L, Alves F, Multhoff G, Dressel R (2007) The heat shock protein HSP70 promotes mouse NK cell activity against tumors that express inducible NKG2D ligands. J Immunol 179:5523-5533

Elsner L, Flügge PF, Lozano J, Muppala V, Eiz-Vesper B, Demiroglu SY, Malzahn D, Herrmann T, Brunner E, Bickeböller H, Multhoff G, Walter L, Dressel R (2010) The endogenous danger signals HSP70 and MICA cooperate in the activation of cytotoxic effector functions of NK cells. J Cell Mol Med 14:992-1002

Fang M, Lanier LL, Sigal LJ (2008) A role for NKG2D in NK cellmediated resistance to poxvirus disease. PLoS Pathog 4:e30

Fodil N, Laloux L, Wanner V, Pellet P, Hauptmann G, Mizuki N, Inoko H, Spies T, Theodorou I, Bahram S (1996) Allelic repertoire of the human MHC class I MICA gene. Immunogenetics 44:351-357

Fojtikova M, Novota P, Cejkova P, Pesickova S, Tegzova D, Cerna M (2011) HLA class II, MICA and PRL gene polymorphisms: the common contribution to the systemic lupus erythematosus development in Czech population. Rheumatol Int 31:1195-1201

Gasser S, Orsulic S, Brown EJ, Raulet DH (2005) The DNA damage pathway regulates innate immune system ligands of the NKG2D receptor. Nature 436:1186-1190

Groh V, Bahram S, Bauer S, Herman A, Beauchamp M, Spies T (1996) Cell stress-regulated human major histocompatibility complex class I gene expressed in gastrointestinal epithelium. Proc Natl Acad Sci U S A 93:12445-12450

Groh V, Rhinehart R, Randolph-Habecker J, Topp MS, Riddell SR, Spies $\mathrm{T}$ (2001) Costimulation of CD8alphabeta T cells by NKG2D via engagement by MIC induced on virus-infected cells. Nat Immunol 2:255-260

Groh V, Wu J, Yee C, Spies T (2002) Tumour-derived soluble MIC ligands impair expression of NKG2D and T-cell activation. Nature 419:734-738

Guerra N, Tan YX, Joncker NT, Choy A, Gallardo F, Xiong N, Knoblaugh S, Cado D, Greenberg NM, Raulet DH (2008)
NKG2D-deficient mice are defective in tumor surveillance in models of spontaneous malignancy. Immunity 28:571-580

Isernhagen A, Malzahn D, Viktorova E, Elsner L, Monecke S, von Bonin F, Kilisch M, Wermuth JM, Walther N, Balavarca Y, Stahl-Hennig C, Engelke M, Walter L, Bickeböller H, Kube D, Wulf G, Dressel R (2015) The MICA-129 dimorphism affects NKG2D signaling and outcome of hematopoietic stem cell transplantation. EMBO Mol Med 7:1480-1502

Jiang X, Zou Y, Huo Z, Yu P (2011) Association of major histocompatibility complex class I chain-related gene A microsatellite polymorphism and hepatocellular carcinoma in South China Han population. Tissue Antigens 78:143-147

Kaiser BK, Yim D, Chow IT, Gonzalez S, Dai Z, Mann HH, Strong RK, Groh V, Spies T (2007) Disulphide-isomerase-enabled shedding of tumour-associated NKG2D ligands. Nature 447:482-486

Kirsten H, Petit-Teixeira E, Scholz M, Hasenclever D, Hantmann H, Heider D, Wagner U, Sack U, Hugo Teixeira V, Prum B, Burkhardt J, Pierlot C, Emmrich F, Cornelis F, Ahnert P (2009) Association of MICA with rheumatoid arthritis independent of known HLA-DRB1 risk alleles in a family-based and a case control study. Arthritis Res Ther 11:R60

Kumar V, Kato N, Urabe Y, Takahashi A, Muroyama R, Hosono N, Otsuka M, Tateishi R, Omata M, Nakagawa H, Koike K, Kamatani N, Kubo M, Nakamura Y, Matsuda K (2011) Genomewide association study identifies a susceptibility locus for HCVinduced hepatocellular carcinoma. Nat Genet 43:455-458

Kumar V, Yi Lo PH, Sawai H, Kato N, Takahashi A, Deng Z, Urabe Y, Mbarek H, Tokunaga K, Tanaka Y, Sugiyama M, Mizokami M, Muroyama R, Tateishi R, Omata M, Koike K, Tanikawa C, Kamatani N, Kubo M, Nakamura Y, Matsuda K (2012) Soluble MICA and a MICA variation as possible prognostic biomarkers for HBV-induced hepatocellular carcinoma. PLoS One 7:e44743

Lavado-Valenzuela R, Benavides M, Carabantes F, Alonso A, Caballero A (2009) MHC class I chain-related gene A transmembrane polymorphism in Spanish women with breast cancer. Tissue Antigens 74:46-49

Leelayuwat C, Townend DC, Degli-Esposti MA, Abraham LJ, Dawkins RL (1994) A new polymorphic and multicopy MHC gene family related to nonmammalian class I. Immunogenetics 40:339-351

Lo PH, Urabe Y, Kumar V, Tanikawa C, Koike K, Kato N, Miki D, Chayama K, Kubo M, Nakamura Y, Matsuda K (2013) Identification of a functional variant in the MICA promoter which regulates MICA expression and increases HCV-related hepatocellular carcinoma risk. PLoS One 8:e61279

Lopez-Hernandez R, Valdes M, Lucas D, Campillo JA, Martinez-Garcia P, Salama H, Lopez M, Salgado G, Botella C, Minguela A, Miras M, Alvarez-Lopez MR, Carballo F, Muro M (2010) Association analysis of MICA gene polymorphism and MICA-129 dimorphism with inflammatory bowel disease susceptibility in a Spanish population. Hum Immunol 71:512-514

Lü M, Xia B, Ge L, Li Y, Zhao J, Chen F, Zhou F, Zhang X, Tan J (2009) Role of major histocompatibility complex class I-related molecules A*A5.1 allele in ulcerative colitis in Chinese patients. Immunology 128:e230-236

Luo QZ, Lin L, Gong Z, Mei B, Xu YJ, Huo Z, Yu P (2011) Positive association of major histocompatibility complex class I chainrelated gene A polymorphism with leukemia susceptibility in the people of Han nationality of Southern China. Tissue Antigens 78: $178-184$

Mellergaard M, Skovbakke SL, Schneider CL, Lauridsen F, Andresen L, Jensen H, Skov S (2014) N-glycosylation of asparagine 8 regulates surface expression of major histocompatibility complex class I chain-related protein A (MICA) alleles dependent on threonine 24. J Biol Chem 289:20078-20091

Mizuki N, Ota M, Kimura M, Ohno S, Ando H, Katsuyama Y, Yamazaki M, Watanabe K, Goto K, Nakamura S, Bahram S, Inoko H (1997) 
Triplet repeat polymorphism in the transmembrane region of the MICA gene: a strong association of six GCT repetitions with Behcet disease. Proc Natl Acad Sci U S A 94:1298-1303

Moenkemeyer M, Heiken H, Schmidt RE, Witte T (2009) Higher risk of cytomegalovirus reactivation in human immunodeficiency virus-1infected patients homozygous for MICA5.1. Hum Immunol 70: $175-178$

Novota P, Kolostova K, Pinterova D, Novak J, Weber P, Treslova L, Kovar J, Andel M, Cerna M (2005) Association of MHC class I chain related gene-A microsatellite polymorphism with the susceptibility to T1DM and LADA in Czech adult patients. Int J Immunogenet 32:273-275

Ota M, Katsuyama Y, Mizuki N, Ando H, Furihata K, Ono S, PivettiPezzi P, Tabbara KF, Palimeris GD, Nikbin B, Davatchi F, Chams H, Geng Z, Bahram S, Inoko H (1997) Trinucleotide repeat polymorphism within exon 5 of the MICA gene (MHC class I chain-related gene A): allele frequency data in the nine population groups Japanese, Northern Han, Hui, Uygur, Kazakhstan, Iranian, Saudi Arabian, Greek and Italian. Tissue Antigens 49:448-454

Pollock RA, Chandran V, Pellett FJ, Thavaneswaran A, Eder L, Barrett J, Rahman P, Farewell V, Gladman DD (2013) The functional MICA129 polymorphism is associated with skin but not joint manifestations of psoriatic disease independently of HLA-B and HLA-C. Tissue Antigens 82:43-47

Raache R, Belanteur K, Amroun H, Benyahia A, Heniche A, Azzouz M, Mimouni S, Gervais T, Latinne D, Boudiba A, Attal N, Abbadi MC (2012) Association of major histocompatibility complex class 1 chain-related gene a dimorphism with type 1 diabetes and latent autoimmune diabetes in adults in the Algerian population. Clin Vaccine Immunol 19:557-561

Raulet DH, Gasser S, Gowen BG, Deng W, Jung H (2013) Regulation of ligands for the NKG2D activating receptor. Annu Rev Immunol 31: 413-441

Roda-Navarro P, Reyburn HT (2009) The traffic of the NKG2D/Dap10 receptor complex during natural killer (NK) cell activation. J Biol Chem 284:16463-16472

Salih HR, Rammensee HG, Steinle A (2002) Cutting edge: downregulation of MICA on human tumors by proteolytic shedding. J Immunol 169:4098-4102

Shafi S, Vantourout P, Wallace G, Antoun A, Vaughan R, Stanford M, Hayday A (2011) An NKG2D-mediated human lymphoid stress surveillance response with high interindividual variation. Sci Transl Med 3:113-124

Skov S, Pedersen MT, Andresen L, Straten PT, Woetmann A, Odum N (2005) Cancer cells become susceptible to natural killer cell killing after exposure to histone deacetylase inhibitors due to glycogen synthase kinase-3-dependent expression of MHC class I-related chain A and B. Cancer Res 65:11136-11145
Steinle A, Li P, Morris DL, Groh V, Lanier LL, Strong RK, Spies T (2001) Interactions of human NKG2D with its ligands MICA, MICB, and homologs of the mouse RAE-1 protein family. Immunogenetics 53:279-287

Tamaki S, Sanefuzi N, Ohgi K, Imai Y, Kawakami M, Yamamoto K, Ishitani A, Hatake K, Kirita T (2007) An association between the MICA-A5.1 allele and an increased susceptibility to oral squamous cell carcinoma in Japanese patients. J Oral Pathol Med 36:351-356

Tamaki S, Kawakami M, Yamanaka Y, Shimomura H, Imai Y, Ishida J, Yamamoto K, Ishitani A, Hatake K, Kirita T (2009) Relationship between soluble MICA and the MICA A5.1 homozygous genotype in patients with oral squamous cell carcinoma. Clin Immunol 130: 331-337

Tian W, Zeng XM, Li LX, Jin HK, Luo QZ, Wang F, Guo SS, Cao Y (2006) Gender-specific associations between MICA-STR and nasopharyngeal carcinoma in a southern Chinese Han population. Immunogenetics 58:113-121

Tong HV, Toan NL, Song LH, Bock CT, Kremsner PG, Velavan TP (2013) Hepatitis B virus-induced hepatocellular carcinoma: functional roles of MICA variants. J Viral Hepat 20:687-698

Tonnerre P, Gerard N, Chatelais M, Poli C, Allard S, Cury S, Bressollette C, Cesbron-Gautier A, Charreau B (2013) MICA variant promotes allosensitization after kidney transplantation. J Am Soc Nephrol 24: 954-966

Triolo TM, Baschal EE, Armstrong TK, Toews CS, Fain PR, Rewers MJ, Yu L, Miao D, Eisenbarth GS, Gottlieb PA, Barker JM (2009) Homozygosity of the polymorphism MICA5.1 identifies extreme risk of progression to overt adrenal insufficiency among 21hydroxylase antibody-positive patients with type 1 diabetes. J Clin Endocrinol Metab 94:4517-4523

Waldhauer I, Goehlsdorf D, Gieseke F, Weinschenk T, Wittenbrink M, Ludwig A, Stevanovic S, Rammensee HG, Steinle A (2008) Tumorassociated MICA is shed by ADAM proteases. Cancer Res 68: 6368-6376

Wesselkamper SC, Eppert BL, Motz GT, Lau GW, Hassett DJ, Borchers MT (2008) NKG2D is critical for NK cell activation in host defense against Pseudomonas aeruginosa respiratory infection. J Immunol 181:5481-5489

Yoshida K, Komai K, Shiozawa K, Mashida A, Horiuchi T, Tanaka Y, Nose M, Hashiramoto A, Shiozawa S (2011) Role of the MICA polymorphism in systemic lupus erythematosus. Arthritis Rheum 63:3058-3066

Zhao J, Jiang Y, Lei Y, Zou K, Wang C, Huang S, Yi F, Xia B (2011) Functional MICA-129 polymorphism and serum levels of soluble MICA are correlated with ulcerative colitis in Chinese patients. J Gastroenterol Hepatol 26:593-598 